\title{
PERANCANGAN SISTEM TANGGAP DARURAT MENGGUNAKAN FRAMEWORK TOGAF
}

\author{
Sintaria Br Sembiring \\ Fakulatas Teknologi Informasi, Universitas Advent Indonesia
}

\begin{abstract}
Abstrak
Permasalahan yang sering terjadi pada saat tanggap darurat adalah terlambatnya pemberian bantuan kepada pengungsi. Beberapa faktor mengapa keterlambatan ini sering terjadi adalah: Harus melewati beberapa prosedur birokrasi yang berlaku, adanya pembedaan wilayah bencana, keterlambatan informasi yang sampai kepada pemerlntah. Badan Penanggulangan Bencana Daerah (BPBD) yang bertanggung jawab dalam penanganan tanggap darurat. Untuk menjalankan fungsinya, BPBD perlu dilengkapi dengan sebuah sistem informasi yang sesuai strategi bisnis organisasi dan dapat membantu BPBD mencapai tujuan bisnisnya. Penelitian ini bertujuan untuk membuat perencanaan arsitektur sistem informasi, dan menghasilkan blueprint pengembangan sistem informasi pada tahap tanggap darurat.
\end{abstract}

Kata-kata Kunci: Arsitektur enterprise, TOGAF, Framework, penanggulangan bencana, sistem Informasis

\section{DESIGN OF EMERGENCY RESPONSE SYSTEM USING TOGAF FRAMEWORK}

\begin{abstract}
The most frequent problem of emergency response is the delay in providing assistance to refugees, some of the factors why this delay is common: It must go through some bureaucratic procedures, the differentiation of disaster areas, and the delays in Information that reach the government. Badan penangulangan bencana daerah (BPBD) responsible for handling emergency response. To carry out its functions, BPBD needs to be equipped with an information system that suits the organization '5 business strategy and can help BPBD achieve its business objectives. This study aims to make the information system architecture planning, and produce blueprint development of information systems at the emergency response stage.
\end{abstract}

Keywords: Enterprise architecture, TOGAF, Framework, disaster management, information systems

\section{Pendahuluan}

Jawa barat merupakan salah satu provinsi yang rawan dengan bencana. Peningkatan bencana terjadi setiap tahunnya, menurut Kepala Seksi Kedaruratan, Badan penangulangan bencana Daerah (BPBD) Provinsi Jawa Barat, Budiman mengatakan Data tiga tahun terakhir menyebutkan kejadian bencana di Jabar setiap tahunnya naik, Ia merinci pada tahun 2015 lalu tercatat sebanyak 532 kejadian bencana tahun 2016 sebanyak 1.133 kejadian dan pada tahun 2017 tercatat sebanyak 1.500 kejadian bencana. (nasional.republika.co.id, 2017)

Menurut undang-undang nomor 24 tahun 2007 tentang tanggap darurat, pasal 33 huruf B dan pasal 48 tentang penyelenggaraan tanggap darurat pada saat tanggap darurat dilakukan pengkajian secara cepat dan tepat terhadap lokasi, kerusakan, dan sumber daya, penentuan status keadaan darurat bencana, penyelamatan dan evakuasi masyarakat terkena bencana, pemenuhan kebutuhan

dasar, perlindungan terhadap kelompok rentan dan pemulihan dengan segera prasarana dan sarana Vital. (BNPB.UU.N0.24, 2007)

Pada tahap tanggap darurat permasalahan yang sering terjadi adalah terlambatnya pemberian bantuan kepada pengungsi, ada beberapa faktor mengapa keterlambatan ini sering terjadi:

1. Harus melewati beberapa prosedur birokrasi yang berlaku, sehingga mengakibatkan bantuan mengalami keterlambatan sampai kepada pengungsi.

2. Adanya pembedaan wilayah bencana.

3. Keterlambatan informasi yang sampai kepada pemerintah. 
Pada saat situasi tanggap darurat, diperlukan suatu sistem yang andal dan akurat, bertujuan untuk mendukung dalam proses pengiriman bantuan dan menolong orang-orang terkena dampak bencana. Keterlambatan penangganan dan seringnya kesimpangsiuran informasi, mempersuiit bagi petugas untuk menangani darurat bencana. Informasi peristiwa bencana sangat diperlukan oleh masyarakat, masyarakat perlu mengetahui resiko»resiko apa saja yang terjadi yang diakibatkan oleh bencana. Dengan adanya sistem yang dibangun diharapkan dapat meminimal segala permasalahan yang umum terjadi seperti kecukupan logistik, distribusi, penanggulangan korban dan sebagainya.

Berdasarkan uraian di atas diperlukan sebuah perencanaan arsitektur sistem informasi agar sistem yang dikembangkan sesuai dengan kebutuhan dan kebijakan tanggap darurat sesuai dengan peraturan pemerintah dan UU yang ada.

Adapun identifikasi masalah dari penelitian ini yaitu bagaimana mengidentifikasi ketersediaan teknologi informasi yang ada saat ini dan tren perkembangan teknologi yang akan datang yang dapat dimanfaatkan untuk membangun sistem tanggap darurat. Tujuan Iainnya adaiah bagaimana merancang sebuah arsitektur sistem informasi yang sesuai untuk tanggap darurat yang sesuai dengan kebutuhan di Indonesia dan sesuaikan dengan amanat Undang-undang.

Penelitian ini dilakukan untuk tujuan mengidentifikasi ketersediaan teknoiogi yang ada dan peranan sistem informasi dalam tanggap darurat di Jawa Barat, serta untuk merancang arsitektur sistem informasi tanggap darurat di Jawa Barat.

Adapun ruang lingkup yang akan dibahas dari peneiitian yaitu membuat perencanaan arsitektur sistem informasi Tanggap Darurat di Jawa Barat mengunakan kerangka kerja The Open Group Architecture Framework (TOGAF).

\section{Metode Penelitian}

Metodologi penelitian ini mengunakan framework The Open Group Architecture Framework (TOGAF). Penekanan dilakukan dalam 6 fase pertama TOGAF, diharapkan dapat menjawab segala kebutuhan untuk memodelkan arsitektur dalam tanggap darurat. Keenam fase tersebut meliputi tahap Architecture Vision, Business Architecture, sistem Information architecture, tehno/ogy architekture, Opportunities and Solution, dan Migration Planning.

\section{Hasil Dan Pembahasan}

Pada fase architecture vision berfungsi untuk memahami visi, misi, tujuan dan sasaran bisnis dalam proses perencanaan arsitektur enterprise.

\section{a. Visi, misi dan Tujuan Bisnis (business goals)}

Visi dan misi tanggap darurat adalah mengembangkan sebuah sistem informasi yang dapat digunakan untuk mengkoordinir, menyalurkan, menginformasikan dan mendukung proses

penanganan pengungsi.

Tujuan bisnis tanggap darurat:

1. Mempercepat waktu respon untuk penetapan status tanggap darurat.

2. Sistem informasi yang dibangun dapat meningkatkan tingkat jaminan ketersedian kebutuhan dasar korban selama status anggap darurat.

\section{b. Sasaran Bisnis (business objectives)}

Sasaran bisnis yang ingin dicapai dalam perencanaan arsitektur enterprise sistem informasi tanggap darurat, antara Iain:

1. Sistem informasi yang dikembangkan harus dapat memperkirakan tingkat kerusakan, iuas cakupan wilayah terdampak, dan jumlah korban jiwa sehingga mempermudah proses penaksiran kondisi wilayah yang terdampak bencana.

2. Sistem informasi yang dibangun dapat mempermudah koordinasi antara lembaga-lembaga terkait dalam proses perencanaan, pelaksanaan dan monitoring proses tanggap darurat.

3. Sistem informasi yang dibangun harus dapat mendukung proses penanganan pengungsi, pengeiolaan bantuan, manajemen relawan, pendataan korban dan kerusakan dan Tindakan Iainnya dalam proses tanggap darurat.

4. Sistem informasi yang dikembangkan dapat menyediakan informasi tentang korban terdampak, kerusakan yang ditimbulkan, ketersediaan logistik, ketersediaan sarana dan sumber daya manusia.

\section{c. Stakeholder}


Stakeholder akan terkait dengan proyek pengembangan sistem informasi ini, pihak-pihak yang berhubungan dengan proses tanggap darurat, antara lain: Pemerintah Pusat, BNPB, Pemerintah Daerah, BPBD, PUSDALOPS, masyarakat Terdampak, LSM. Table 1.

Mekanisme hubungan antara sistem informasi yang akan dibangun dengan srakeha/der dapat dilihat pada

Tabel 1 Mekanisme hubungan sistem informasi dengan stakeholder

\begin{tabular}{|c|c|c|}
\hline No & Stakeholder & Mekanisme Hubungan \\
\hline 1 & $\begin{array}{c}\text { Pemerintah } \\
\text { Pusat BNPB } \\
\text { Pemerintah } \\
\text { Daerah } \\
\text { BPBD } \\
\text { PUSDALOPS }\end{array}$ & $\begin{array}{l}\text { a. Perkiraan dampak kerugian, kerusakan dan korban } \\
\text { bencana. } \\
\text { b. Koordinasi penetapan status tanggap darurat. } \\
\text { c. Pengalokasian dana dan sumber daya lain. } \\
\text { d. Dokumentasi kejadian } \\
\text { e. Pengelolaan sarana dan prasarana } \\
\text { f. Membuat peta bencana } \\
\text { g. Pengadaan bantuan, distribusi dan pembagian } \\
\text { bantuan kepada korban bencana. } \\
\text { h. Identifikasi kerusakan dan kerugian akibat bencana. }\end{array}$ \\
\hline 2 & $\begin{array}{l}\text { Masyarakat } \\
\text { Terdampak }\end{array}$ & a. Pendataan korban dan pencarian korban bencana. \\
\hline 3 & LSM & $\begin{array}{l}\text { a. Pendaftaran dan pendataan relawan } \\
\text { b. Pendataan bantuan } \\
\text { c. Membantu mengerahkan relawan }\end{array}$ \\
\hline
\end{tabular}

\section{Fase Business Architecture}

Fase Business Architecture merupakan pemahaman mengenai bagaimana proses tanggap darurat dilakukan dengan menggunakan pemodelan arsitektur bisnis. Tahapan yang dilakukan pada fase business architecture adalah :

\section{a. Proses bisnis tanggap darurat}

Permasalahan yang sering timbul dalam proses bisnis tanggap darurat bencana adalah lambatnya respon pemerintah ketika sebuah bencana teljadi. Hal ini disebabkan oleh beberapa hal, antara Iain:

1. Kurangnya informasi besaran dampak yang ditimbulkan ketika bencana terjadi, sehingga pengambil keputusan lambat dalam menentukan status sebuah bencana.

2. Kurangnya koordinasi antara lembaga-lembaga yang terkait sehingga proses tanggap darurat tidak berjalan sebagaimana mestinya sesuai dengan amanat undang-undang.

Untuk membantu mempercepat proses penetapan status bencana, maka perlu dilakukan proses pengumpulan data dan informasi bencana, kemudian dilakukan simulasi dan perkiraan dampak bencana. Kemudian proses koordinasi antar Lembaga-lembaga yang bertanggung jawab perlu dilakukan dengan memberlakukan prosedur baku dan standar layanan yang baik serta didukung informasi dan data yang akurat. Model bisnis proses tanggap darurat dapat dilihat pada Gambar 1

di bawah ini. 


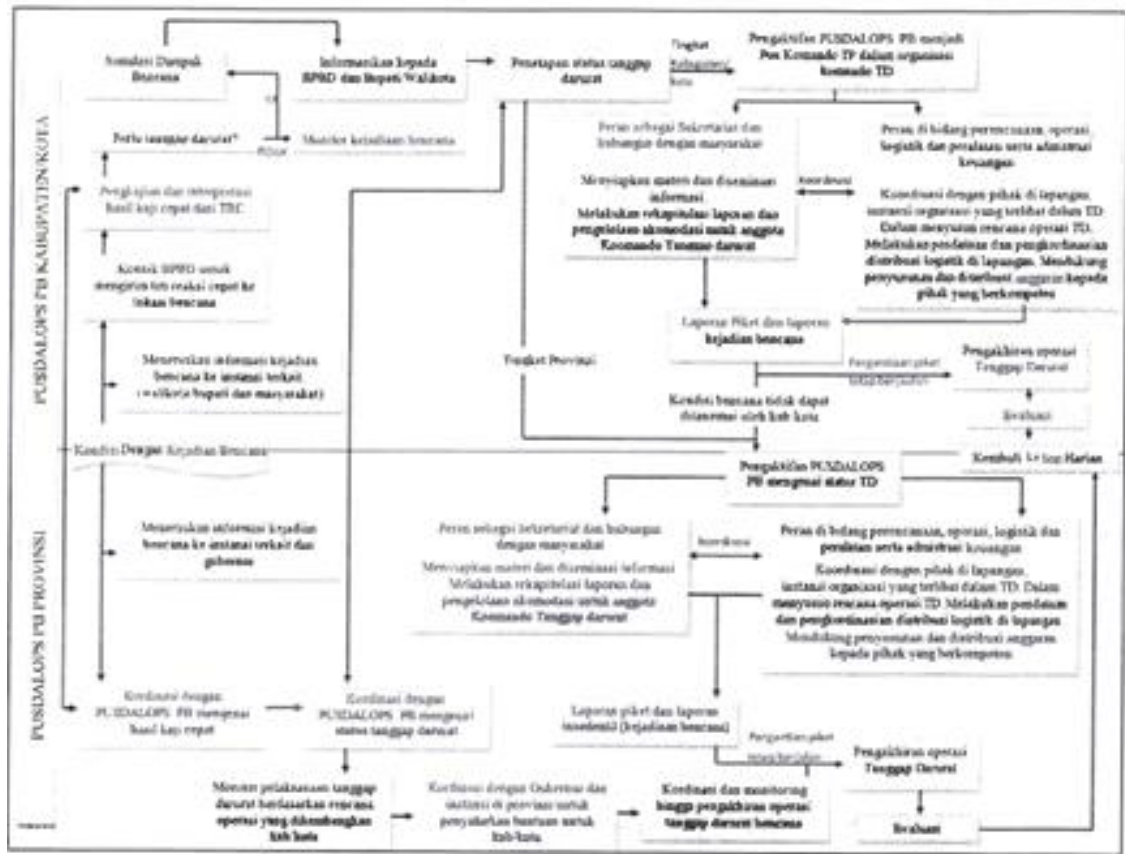

Gambar 1 Proses bisnis tanggang darurat

\section{b. Diagram Use Case}

Adapun diagram use case dari sistem tanggap darurat yang dirancang ini terdiri dari tiga aktor utama yaitu Operator, BPBD dan Pusdalops, yang hubungannya dapat dijelaskan sesuai dengan gambar 2 berikut.

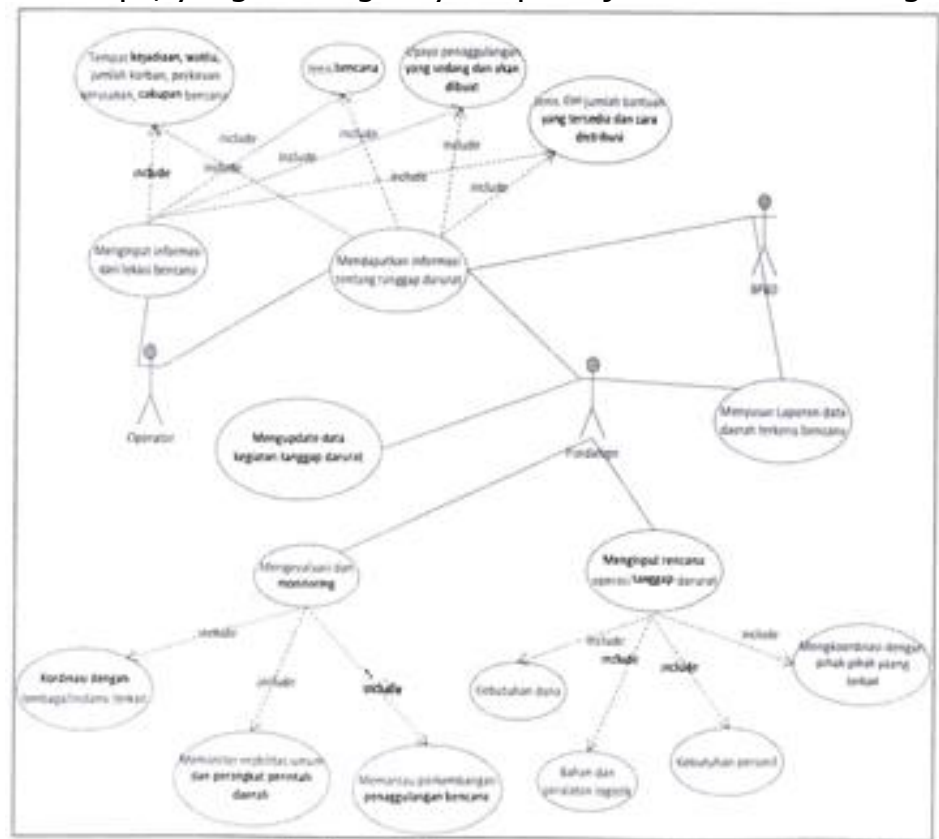

Gambar 2 Use case tanggap darurat

\section{c. Area fungsional penerapan penanggulan bencana}

Dari diagram use case menunjukkan fungsionalitas suatu sistem yang berinteraksi dengan penerapan penanggulangan bencana. Hasil pemeteaan area fungsional dapat dilihat pada tabel 2.

Tabel 2 Area fungsional Penerapan penanggulangan bencana

\begin{tabular}{|c|l|l|c|c|}
\hline $\begin{array}{c}\text { Fungsi } \\
\text { Bisnis }\end{array}$ & $\begin{array}{l}\text { Kebutu } \\
\text { han }\end{array}$ & Akuisisi & Pengelolaan & Disposisi \\
\hline Proses & Perenca & -Melaksanakan & -Perumusan & - Menyusun \\
\hline
\end{tabular}




\begin{tabular}{|c|c|c|c|c|}
\hline $\begin{array}{l}\text { Tanggap } \\
\text { Darurat }\end{array}$ & $\begin{array}{c}\text { Naan } \\
\text { strategi } \\
\text { kedarur } \\
\text { atan }\end{array}$ & $\begin{array}{c}\text { pengkajian } \\
\text { secara } \\
\text { cepat dan tepat } \\
\text { terhadap lokasi, } \\
\text { kerusakan, } \\
\text { kerugian, } \\
\text { sumber daya } \\
\text {-Menentukan } \\
\text { keadaan } \\
\text { Status keadaan } \\
\text { darurat } \\
\text { Bencana } \\
\text {-Melaksanakan } \\
\text { pendistribusian } \\
\text { logistic } \\
\text { dan peralatan } \\
\text {-Menyelamatkan } \\
\text { dan } \\
\text { mengevakuasi } \\
\text { masyarakat } \\
\text { terkena } \\
\text { bencana. } \\
\text {-Melaksanakan } \\
\text { pemantauan, } \\
\text { evaluasi } \\
\text { dan analisis } \\
\text { pelaporan } \\
\text { tentang } \\
\text { pelaksanaan } \\
\text { kebijakan umum } \\
\text { dibidang logistic } \\
\text { dan } \\
\text { peralatan }\end{array}$ & $\begin{array}{l}\text { Kebijakan } \\
\text { umum } \\
\text { Pada saat } \\
\text { penanganan } \\
\text { pengungsi, } \\
\text { logistic } \\
\text { dan peralatan. } \\
\text {-Penghimpunan, } \\
\text { pengolahan, } \\
\text { penyajian data } \\
\text { dan } \\
\text { penyusunan } \\
\text { rencana dan } \\
\text { petunjuk teknis } \\
\text { lingkup } \\
\text { kedaruratan } \\
\text { dan logistik. } \\
\text {-Pelaksanaan } \\
\text { penyusunan } \\
\text { perencanaan } \\
\text { logistic } \\
\text { dan peralatan } \\
\text { - } \\
\text { Pengkoordinasian } \\
\text { dan } \\
\text { pelaksanaan } \\
\text { kebijakan umum } \\
\text { pada } \\
\text {-Komando } \\
\text { pelaksaan } \\
\text { tanggap darurat } \\
\text { - } \\
\text { Pengkoordinasian } \\
\text { dan } \\
\text { pelaksanaan } \\
\text { hubungan kerja } \\
\text { dengan instansi } \\
\text { atau lembaga } \\
\text { terkati } \\
\text { dibidang } \\
\text { tanggap } \\
\text { darurat dan } \\
\text { penangan } \\
\text { pengungsi. } \\
\text {-Pemantauan, } \\
\text { evaluasi dan } \\
\text { analisis } \\
\text { pelaporan } \\
\text { tentang } \\
\text { pelaksanaan } \\
\text { kebijakan umum }\end{array}$ & $\begin{array}{c}\text { rencana } \\
\text { operasi } \\
\text { - Mengaktifkan } \\
\text { Pusat } \\
\text { Pengendali } \\
\text { Operasi } \\
\text { (Pusdalops) } \\
\text { menjadi Pos } \\
\text { Komando } \\
\text { Tanggap } \\
\text { darurat } \\
\text { (BPBD) } \\
\text { - Memebentuk Pos } \\
\text { Komando } \\
\text { Lapangan di } \\
\text { lokasi } \\
\text { bencana, } \\
\text { - Membuat rencana } \\
\text { strategis dan taktis, } \\
\text { mengorganisasikan, } \\
\text { melaksanakan dan } \\
\text { mengendalikan } \\
\text { operasi tanggap } \\
\text { darurat, } \\
\text { - Melaksanakan } \\
\text { komando dan } \\
\text { pengendalian untuk } \\
\text { pengarahan SDM, } \\
\text { peralatan logistik } \\
\text { dan penyelamatan }\end{array}$ \\
\hline
\end{tabular}

\section{d. Identifikasi Fungsi Bisnis Penanggulangan Bencana}

Pada tahap selanjutnya dilakukan pengidentifikasian fungsi bisnis pada penanggulangan bencana, setelah dilakukan identifikasi maka didapat fungsi-fungsi bisnis secara keseluruhan. Hasil identifikasi bisa dilihat pada tabel 3. 
Tabel 3 Identifikasi fungsi bisnis penanggulangan bencana terhadap area fungsional Pusdalops BPBD Jawa Barat

\begin{tabular}{|c|c|c|}
\hline No & $\begin{array}{c}\text { Area } \\
\text { Fungsional }\end{array}$ & Fungsi Bisnis Penanggulangan Bencana \\
\hline 1. & BPBD & $\begin{array}{l}\text { a. Mengupdate dan cross check data kesiapsiagaan } \\
\text { b. Laporan data daerah terkena bencana } \\
\text { c. Mendapatkan informasi tentang tanggap darurat } \\
\text { d. Laporan dan evaluasi kegiatan penyaluran logistic } \\
\text { e. Laporan pelaksanaan kerja kegiatan penyediaan sarana dan } \\
\text { prasarana } \\
\text { f. Laporan kinerja SDM } \\
\text { g. Laporan penggunaan dana }\end{array}$ \\
\hline 2. & Pusdalops & $\begin{array}{l}\text { a. Memantau informasi dan menganalisa kejadian bencana } \\
\text { b. Mendapatkan informasi tentang tanggap darurat } \\
\text { c. Mengupdate data kegiatan tanggap darurat } \\
\text { d. Menyusun Laporan data daerah terkena bencana } \\
\text { e. Menginput rencana operasi tanggap darurat } \\
\text { f. Mengevaluasi dan monitoring }\end{array}$ \\
\hline 3. & Operator & $\begin{array}{l}\text { a. Mengidentifikasi sumber bahaya dan ancaman bencana } \\
\text { b. Mengidentifikasi kategori status aman atau siaga } \\
\text { c. Memantau informasi dan menganalisa kejadian bencana } \\
\text { d. Menginput informasi dari lokasi bencana } \\
\text { e. Mendapatkan informasi tentang tanggap darurat }\end{array}$ \\
\hline 4. & Supervisor & a. Memantau informasi dan menganalisa kejadian bencana \\
\hline 5. & Seksi Logistik & $\begin{array}{l}\text { a. Menginput penyusunan kebijakan, koordinasi, fasilitas logistic } \\
\text { kebencanaan } \\
\text { b. Input kebutuhan barang/jasa, peralatan kebutuhan logistic } \\
\text { c. Mengupdate data dan informasi logistic kebencanaan } \\
\text { d. Melaporkan dan evaluasi kegiatan penyaluran logistic } \\
\text { e. Menginput data logistic masuk dan data keluar } \\
\text { f. Mencocokkan data di manifest dengan jenis bantuan yang } \\
\text { g. Menginput tempat, tanggal, waktu kedatangan bantuan } \\
\text { g. }\end{array}$ \\
\hline 6. & $\begin{array}{l}\text { Warehouse } \\
\text { Logistik }\end{array}$ & $\begin{array}{l}\text { a. Menginput data logistic masuk dan data keluar } \\
\text { b. Mengecek ketersediaan stock logistic } \\
\text { c. Input rencana pendistribusian logistic } \\
\text { d. Pengambilan logistic untuk didistribusikan } \\
\text { e. Input data yang dibutuhkan untuk pengangkutan } \\
\text { f. Input jenis pengangkutan }\end{array}$ \\
\hline 7. & Penerima & $\begin{array}{l}\text { a. Mencocokkan data di manifest dengan jenis bantuan yang } \\
\text { diterima } \\
\text { b. Menginput tempat, tanggal, waktu kedatangan bantuan }\end{array}$ \\
\hline 8. & Tim SDM & $\begin{array}{l}\text { a. Input tim yang bertugas dalam penanggulangan bencana } \\
\text { b. Memberikan informasi kebutuhan SDM untuk penanggulangan } \\
\text { bencana } \\
\text { c. Update SDM yang digunakan } \\
\text { d. Monitoring dan evaluasi kinerja SDM } \\
\text { e. Melaporkan kinerja SDM }\end{array}$ \\
\hline 9. & Seksi Finansial & $\begin{array}{l}\text { a. Input rencana penggunaaan dana (budgeting) untuk biaya } \\
\text { kegiatan } \\
\text { b. Input dana masuk untuk biaya kegiatan } \\
\text { c. Laporan dana masuk } \\
\text { d. Input dana keluar yang digunakan untuk biaya kegiatan } \\
\text { e. Mengupdate penggunaan dana } \\
\text { f. Monitoring dan evaluasi penggunaan dana } \\
\text { g. Melaporkan penggunaan dana }\end{array}$ \\
\hline
\end{tabular}




\section{Fase Information System Architecture}

Fase ini terdiri dari 2 (dua) fase pengembangan, yaitu fase pengembangan arsitektur aplikasi dan fase pengembangan arsitektur data.

\section{Fase Application Architecture}

Pada tahap ini dilakukan mengidentiflkasi aplikasi apa saja yang perlu ditambahkan untuk mendukung fungsi bisnis yang ada. Setelah diidentifikasi aplikasi apa saja yang perlu ditambahkan maka didefinisikan hubungan antara aplikasi tersebut dengan fungsi bisnis yang ada:

\section{a. Daftar kandidat modul aplikasi}

Tabel 4 Daftar Kandidat Aplikasi

\begin{tabular}{|c|c|c|}
\hline No & Kelompok & Kandidat Aplikasi \\
\hline 1. & $\begin{array}{lll}\text { Sistem Informasi Tanggap } \\
\text { Darurat }\end{array}$ & $\begin{array}{l}\text { 1. Aplikasi Simulasi dan Assesement Bencana } \\
\text { 2. Aplikasi korban dan Kerusakan Bencana } \\
\text { 3. Aplikasi Penanganan Medis dan SAR } \\
\text { 4. Aplikasi Pengelolaan Relawan }\end{array}$ \\
\hline 2. & $\begin{array}{l}\text { Sistem pembentukan tim } \\
\text { penanganan bencana }\end{array}$ & Aplikasi Sistem Logistik \\
\hline 3. & Sistem pengadaan logistik & Aplikasi Sistem Logistik \\
\hline 4. & \begin{tabular}{lll}
\multicolumn{1}{c}{ Sistem } & perencanaan \\
administrasi & dan & pengelolaan \\
finansial
\end{tabular} & Aplikasi manajemen finansial \\
\hline
\end{tabular}

Pada tahapan ini dilakukan pengidentifkasian aplikasi yang digunakan untuk mendukung fungsi bisnis. Daftar kandidat aplikasi yang digunakan untuk mendukung fungsi utama penanggulang bencana BPBD Provinsi Jabar dapat dilihat pada Tabel 4.

\section{b. Relasi fungsi bisnis dengan modul aplikasi}

Relasi fungsi bisnis dengan aplikasi yang ada digunakan untuk menunjukkan kapan dan bagaimana sebuah aplikasi berperan dalam proses tanggap darurat. Relasi antara fungsi bisnis dengan aplikasi ditunjukkan pada Tabel 5 di bawah.

Tabel 5 Relasi fungsi bisnis dengan aplikasi

\begin{tabular}{|c|c|c|c|c|c|c|c|c|c|c|c|}
\hline \multirow[t]{2}{*}{ No } & \multirow[t]{2}{*}{ Fungsi Bisnis } & & & & & & \multirow[b]{2}{*}{5.1} & \multirow[b]{2}{*}{5.2} & \multirow[b]{2}{*}{5.3} & \multirow[b]{2}{*}{6.1} & \multirow[b]{2}{*}{7.1} \\
\hline & & 1.1 & 1.2 & 2.1 & 3.1 & 4.1 & & & & & \\
\hline 1. & \begin{tabular}{l}
\multicolumn{2}{c}{ Laporan data } \\
daerah terkena \\
bencana
\end{tabular} & & & & & & $x$ & & & & \\
\hline 2. & \begin{tabular}{l}
\multicolumn{2}{c}{ Mendapatkan } \\
informasi tentang \\
tanggap darurat
\end{tabular} & & & & & & & & $\mathrm{x}$ & & \\
\hline 3. & $\begin{array}{l}\text { Laporan dan } \\
\text { evaluasi penyaluran } \\
\text { logistik }\end{array}$ & & & & & & & & & $\mathrm{x}$ & \\
\hline 4. & SDM & & & & & $x$ & & & $\mathrm{x}$ & & \\
\hline 5. & $\begin{array}{c}\text { Laporan } \\
\text { pengguna dana }\end{array}$ & & & & & & & & $\mathrm{x}$ & & $x$ \\
\hline 6. & \begin{tabular}{l}
\multicolumn{2}{c}{ Pentapan } \\
status \\
darurat
\end{tabular} & & & & & & & & $x$ & & \\
\hline 7. & $\begin{array}{cr}\text { Aktifkan } & \text { pos } \\
\text { Tangqap } & \text { darurat }\end{array}$ & & & & & & & & $x$ & & \\
\hline
\end{tabular}




\begin{tabular}{|c|c|c|c|c|c|c|c|c|c|c|c|}
\hline & $\begin{array}{ll}\text { dan } & \text { Sekretariat } \\
\text { Tanggap darurat }\end{array}$ & & & & & & & & & & \\
\hline 8. & $\begin{array}{l}\text { Pendataan } \\
\text { korban terdampak } \\
\text { bencana dan lokasi } \\
\text { posko pengungsi }\end{array}$ & $x$ & & & & & & & $x$ & & \\
\hline 9. & \begin{tabular}{lr}
\multicolumn{2}{c}{ Penyaluran } \\
bantuan & untuk \\
korban & dampak \\
bencana &
\end{tabular} & $x$ & & & & & $x$ & & & $x$ & \\
\hline 10. & \begin{tabular}{l}
\multicolumn{1}{c}{ Penerminaan } \\
bantuan untuk \\
korban bencana cari \\
lembaga donor
\end{tabular} & & & & & & $x$ & & & & \\
\hline 11. & $\begin{array}{l}\text { Distribusi } \\
\text { bantuan ke posko- } \\
\text { posko penqungsi }\end{array}$ & $x$ & & & & & $\mathrm{x}$ & & & $x$ & \\
\hline 12. & $\begin{array}{c}\text { Pencarian } \\
\text { korban bencana }\end{array}$ & $x$ & $x$ & & & & $x$ & & & & \\
\hline 13. & $\begin{array}{l}\quad \text { Perawatan } \\
\text { medis untuk korban } \\
\text { bencana }\end{array}$ & $x$ & $x$ & & & & $x$ & & & & \\
\hline 14. & \begin{tabular}{l}
\multicolumn{1}{c}{ Pengaturan } \\
distribusi (asigment) \\
rerlawan bencana
\end{tabular} & $x$ & $x$ & $x$ & & $x$ & & & & & \\
\hline 15. & $\begin{array}{l}\text { Evaluasi proses } \\
\text { tangqap darurat }\end{array}$ & $x$ & $x$ & $x$ & & & $\mathrm{x}$ & & & & \\
\hline 16. & $\begin{array}{c}\text { Akhiri proses } \\
\text { tanggap darurat }\end{array}$ & $x$ & $x$ & $x$ & & & $x$ & & & & \\
\hline
\end{tabular}

Keterangan tabel:

1.1 Aplikasi Korban dan Kerusakan Bencana

1.2 Aplikasi Penanganan Medis dan SAR

2.1 Aplikasi Pengelolaan Relawan

3.1 Aplikasi Pengelolaan Ken'asama

4.1 Aplikasi sistem informasi SDM

5.1 Aplikasi Pengelolaan Sarana dan Prasarana

5.2 Aplikasi GIS(Geography Information Systems)

5.3 Aplikasi Infrastruktur Data Spasial Bencana

6.1 Aplikasi Sistem Logistik

7.1 Aplikasi manajement finansial

\section{Fase Data Architecture}

Aplikasi-aplikasi yang ada dapat berjalan apabila didukung oleh arsitektur data yang sesuai dengan kebutuhannya. Oleh sebab itu, pada bagian ini akan dikaji kebutuhan arsitektur data dari sistem informasi yang sedang dibangun.

\section{a. Mendefenisikan Entitas}

Berdasarkan dari entitas bisnis diatas, maka masing «masing entitas bisnis diturunkan menjadi entitas data. Matriks entitas bisnis dan entitas data dapat dilihat pada tabel 6 dibawah ini

Tabel 6 Matriks entitas bisnis dan entitas data

\begin{tabular}{|c|c|c|}
\hline No & Entitas Bisnis & Entitas Data \\
\hline 1. & $\begin{array}{l}\text { Entitas tanggap darurat } \\
\text { bencana }\end{array}$ & $\begin{array}{l}\text { Entitas Korban, Entitas Pengungsian, Entitas Bantuan, } \\
\text { Entitas Relawan, Entitas Type Bencana, Entitas Bencana, } \\
\text { Entitas Posko Bencana, Entitas Lokasi, Entitas Asigment }\end{array}$ \\
\hline
\end{tabular}




\begin{tabular}{|r|l|l|}
\hline & & \\
\hline 2. & $\begin{array}{l}\text { Entitas manajement } \\
\text { sumber daya tim } \\
\text { penanggulangan bencana }\end{array}$ & $\begin{array}{l}\text { Entitas Pemeliharaan, Entitas Pengadaan, Entitas } \\
\text { Pengunaan, Entitas Pencarian, Entitas Lembaga Donor, } \\
\text { Entitas Organisasi/LSM, Entitas Rumah Sakit, Entitas } \\
\text { Perawatan Medis, Entitas Tenaga Medis }\end{array}$ \\
\hline 3. & $\begin{array}{l}\text { Entitas penyediaan dan } \\
\text { penyaluran logistik }\end{array}$ & $\begin{array}{l}\text { Entitas Logistik, Entitas Lokasi, Entitas Distribusi } \\
\text { Bantuan, Entitas Tim Sar }\end{array}$ \\
\hline 4. & $\begin{array}{l}\text { Entitas administrasi dan } \\
\text { pengelolaan finansial }\end{array}$ & Entitas Pendanaan, Entitas Pemberi Dana \\
\hline
\end{tabular}

\section{Fase Technology Architecture}

Fase Technology architecture bertujuan mengidentifikasi teknologi yang akan dibutuhkan dalam pengembangan aplikasi yang direncanakan. Tahapan-tahapan yang diperlukan dalam fase technology Architecture sebagai berikut:

\section{Mengidentifikasi Ketersediaan Teknologi}

Mengidentifikasi prins

ip-prinsip berdasarkan platfrom teknologi yang digunakan untuk menyediakan lingkungan aplikasi yang akan mengelola data. Prinsip-prinsip ini digunakan untuk menenukan platform teknologi yang dapat mendukung dalam tanggap darurat di Pusdalops BPBD Provinsi Jawa Barat. Hasil dari pengidentifikasiaan prinsip-prinsip tersebut dapat dilihat di Tabel 7

Tabel 7 Prinsip-prinsip pengembangan platform teknologi yang akan digunakan

\begin{tabular}{|c|c|c|}
\hline No & Jenis & Prinsip \\
\hline \multirow[t]{4}{*}{1} & \multirow[t]{4}{*}{ Perangkat keras } & a. Mendukung aplikasi berbasis web \\
\hline & & b. Teknologi kompatibel dengan perkembangan yang akan datang \\
\hline & & c. Berdasarkan kebutuhan dan tujuan dari tanggap darurat \\
\hline & & d. Teknologi yang tidak tergantung kepada brand tertentu \\
\hline \multirow[t]{12}{*}{2} & \multirow[t]{12}{*}{ Perangkat Lunak } & a. Sistem operasi dapat mendukung jaringan organisasi \\
\hline & & $\begin{array}{l}\text { b. Sistem operasi dapat mendukung dalam pengembangan sistem } \\
\text { aplikasi }\end{array}$ \\
\hline & & $\begin{array}{l}\text { c. Sistem operasi dapat bersifat multi platform dimana ada beberapa } \\
\text { sistem operasi yang digunakan Bersama-sama }\end{array}$ \\
\hline & & $\begin{array}{l}\text { d. Sistem operasi bersifat interkoneksi dengan platform lain yang } \\
\text { berbeda jenis }\end{array}$ \\
\hline & & e. DBMS dapat mencegah redudansi data \\
\hline & & f. DBMS harus dapat menjaga integritas dan confidentiality data \\
\hline & & g. DBMS dapat menjaga tingkat ketersediaan data yang tinggi \\
\hline & & h. DBMS memungkinkan data di back up dan direcovery dengan mudah \\
\hline & & i. DBMS memungkinkan akses data yang mudah \\
\hline & & $\begin{array}{l}\text { j. DBMS memungkinkan data dimiliki Bersama dan dapat diakses } \\
\text { Bersama-sama (sharing data) }\end{array}$ \\
\hline & & $\begin{array}{l}\text { k. Bahasa pemrograman yang dipilih dapat menghasilkan aplikasi yang } \\
\text { user friendly }\end{array}$ \\
\hline & & $\begin{array}{l}\text { I. Bahasa pemrograman yang dipilih mendukung aplikasi yang berbasis } \\
\text { web }\end{array}$ \\
\hline \multirow[t]{5}{*}{3} & \multirow{5}{*}{$\begin{array}{l}\text { Perangkat } \\
\text { komunikasi }\end{array}$} & a. Mendukung komunikasi dalam jaringan local (LAN) \\
\hline & & $\begin{array}{l}\text { b. Terbuka untuk terkoneksi dengan jaringan yang lain untuk } \\
\text { memaksimalkan penyebaran informasi }\end{array}$ \\
\hline & & c. Mendukung komunikasi dalam jaringan global/internet \\
\hline & & d. Jaringan yang dibangun memiliki bandwith yang cukup \\
\hline & & $\begin{array}{l}\text { e. Dapat terkoneksi dengan jaringan lain yang bebeda jenis (misalnya: } \\
\text { jaringan Internet dengan selular) }\end{array}$ \\
\hline
\end{tabular}




\begin{tabular}{|l|l|l|}
\hline & f. $\begin{array}{l}\text { Dilengkapi dengan teknologi jaringan yang bersifat mobile yang dapat } \\
\text { dipindah-pindah sesuai dengan lokasi bencana. }\end{array}$ \\
\hline
\end{tabular}

\section{Mendefinisikan platform teknologi}

Secara lengkap, hubungan antara aplikasi yang diusulkan dengan kebutuhan jaringan ditunjukkan pada Tabel 8.

Aplikasi dan basis data yang akan dikembangkan akan mengunaan konsep berbasis Web. Konsep berbasis web akan dapat dijalankan mengunakan sistem operasi manapun dan dapat diakses Iewat banyak media. Konsep berbasis web membutuhkan koneksi intranet handal dan stabil, bertujuan agar pada saat aplikasi dijalankan aplikasi tersebut akan berjalan dengan baik dan lancar.

Aplikasi yang dibangun diharapkan dapat digunakan pada proses tanggap darurat dari lokasi bencana. Karena itu, untuk mengantisipasi tidak adanya koneksi akses internet di lokasi bencana,

baik karena rusak akibat bencana maupun karena lokasi bencana yang berada pada daerah terpencil, maka diperlukan sebuah teknologi jaringan menggunakan satelit yang bersifat mobile atau dapat dipasang dan dipindah-pindah dari satu lokasi ke lokasi yang lain.

Tabel 8 Hubungan antara aplikasi dan kebutuhan jaringan

\begin{tabular}{|c|c|c|c|c|c|}
\hline No & Nama Aplikasi & \multicolumn{4}{|c|}{ Kebutuhan Jaringan } \\
\hline 1. & $\begin{array}{l}\text { Aplikasi Korban dan Kerusakan } \\
\text { Bencana }\end{array}$ & $\begin{array}{l}\text { Jaringan, } \\
\text { Internet }\end{array}$ & Internet, & Jaringan & Mobile \\
\hline 2. & $\begin{array}{l}\text { Aplikasi Penanganan Medis dan } \\
\text { SAR }\end{array}$ & $\begin{array}{l}\text { Jaringan, } \\
\text { Internet }\end{array}$ & Internet, & Jar & Iobile \\
\hline 3. & Aplikasi pengelolaan Relawan & $\begin{array}{l}\text { Jaringan, } \\
\text { Internet }\end{array}$ & nternet, & $n$ & Mobile \\
\hline 4. & Aplikasi Pengelolaan Kerjasama & $\begin{array}{l}\text { Jaringan, } \\
\text { Internet }\end{array}$ & nternet, & & Mobile \\
\hline 5. & Aplikasi sistem informasi SDM & $\begin{array}{l}\text { Jaringan, } \\
\text { Internet }\end{array}$ & et, & in & Mobile \\
\hline 6. & $\begin{array}{l}\text { Aplikasi Pengelolaan Sarana dan } \\
\text { Prasarana }\end{array}$ & $\begin{array}{l}\text { Jaringan, } \\
\text { Internet }\end{array}$ & Internet, & jan & Mobile \\
\hline 7. & $\begin{array}{cr}\text { Aplikasi GIS } & \text { (Geography } \\
\text { Information Systems) }\end{array}$ & $\begin{array}{l}\text { Jaringan, } \\
\text { Internet }\end{array}$ & Internet, & gan & Mobile \\
\hline 8. & $\begin{array}{l}\text { Aplikasi Infrastruktur Data Spasial } \\
\text { Bencana }\end{array}$ & $\begin{array}{l}\text { Jaringan, } \\
\text { Internet }\end{array}$ & Internet, & in & Mobile \\
\hline 9. & Aplikasi Sistem Logistik & $\begin{array}{l}\text { Jaringan, } \\
\text { Internet }\end{array}$ & Internet, & an & lobile \\
\hline 10. & Aplikasi ma & $\begin{array}{l}\text { Jaringan, } \\
\text { Internet }\end{array}$ & nternet, & ringan & bile \\
\hline
\end{tabular}

\section{Fase Opportunities and Solution}

Fase ini untuk melihat bagian mana dari arsitektur system yang ada saat ini yang masih dapat dipertahankan, bagian yang perlu dikembangkan dan bagian yang benar-benar harus dihilangkan. Hal ini dapat dilakukan dengan melakukan analisa gap antara kondisi yang ada dengan kondisi yang akan datang dan kemudian diikuti dengan langkah-langkah analisa opportunities dan solutions

\section{a. Perbandingan Aplikasi}

Secara garis besar dapat disimpulkan bahwa kondisi aplikasi yang ada saat ini di Pusdalops BPBD masih sangat minim. Karena itu, tidak mengejutkan jika gap yang ada antara kondisi sekarang dengan kondisi yang diinginkan sangat jauh.

Beberapa aplikasi yang ada masih dapat dimanfaat untuk mendukung fungsi bisnis di Pusdalops BNPB seperti aplikasi Radiokom misalnya. Jaringan Intranet yang dimiliki dapat digunakan bila beberapa aplikasi yang ingin dikembangkan diinginkan memiliki tingkat keamanan yang tinggi. Lebih jelas, perbandingan aplikasi yang ada saat ini dengan aplikasi yang diusulkan dapat dilihat di Tabel 9 di bawah ini. 
Tabel 9 Analisa gap aplikasi yang ada dengan aplikasi yang diusulkan

\begin{tabular}{|c|c|c|c|}
\hline \multicolumn{2}{|c|}{ Kondisi Existing } & \multicolumn{2}{|r|}{ Kondisi yang direncanakan } \\
\hline Aplikasi & Manfaat & Aplikasi & Manfaat \\
\hline${ }_{\text {BIDI }}^{\text {Aplikasi }}$ & $\begin{array}{l}\text { - Pelaporan bencana } \\
\text { - Menyimpan data } \\
\text { bencana } \\
\text { - Analisa statistik } \\
\text { bencana } \\
\text { - Pembelajaran untuk } \\
\text { tanggap darurat }\end{array}$ & \begin{tabular}{l}
\multicolumn{1}{c}{ Aplikasi } \\
Korban dan \\
Kerusakan \\
Bencana
\end{tabular} & $\begin{array}{l}\text { - Pendataan korban jiwa akibat } \\
\text { bencana } \\
\text { - Pendataan korban bencana } \\
\text { - Pendataan kerusakan property } \\
\text { masyarakan dan infrastruktur } \\
\text { terdampak bencana } \\
\text { - Manajemen pengungsi } \\
\text { - Manajemen bantuan dan logistik } \\
\text { untuk tanggap darurat } \\
\text { - Pelaporan proses tanggap darurat }\end{array}$ \\
\hline $\begin{array}{l}\quad \text { Aplikasi } \\
\text { Sistem } \\
\text { Basisdata }\end{array}$ & $\begin{array}{l}\text { - Penyimpanan data } \\
\text { bencana } \\
\text { - Peta bencana } \\
\text { - GIS }\end{array}$ & $\begin{array}{l}\text { Aplikasi } \\
\text { Penanganan } \\
\text { Medis dan SAR }\end{array}$ & $\begin{array}{l}\text { - Manajemen penanganan medis } \\
\text { - Morban bencana } \\
\text { - Manajemen tenaga medis } \\
\text { terlibat } \\
\text { - Manajemen pencarian korban } \\
\text { - Pelaporan penanganan medis } \\
\text { korban bencana }\end{array}$ \\
\hline & & $\begin{array}{l}\text { Aplikasi } \\
\text { Pengelolaan } \\
\text { Relawan }\end{array}$ & $\begin{array}{l}\text { - Pendataan relawan dan organisasi } \\
\text { relawan } \\
\text { - Manajemen relawan tanggap } \\
\text { darurat } \\
\end{array}$ \\
\hline & & \begin{tabular}{l}
\multicolumn{2}{c}{ Aplikasi } \\
sistem informasi \\
SDM
\end{tabular} & - Pengelolaan sumber daya manusia \\
\hline & & \begin{tabular}{l}
\multicolumn{1}{c}{ Aplikasi } \\
Pengelolaan \\
Sarana dan \\
Prasarana
\end{tabular} & $\begin{array}{l}\text { - Pendataan sarana dan prasarana } \\
\text { BPBD } \\
\text { - Manajemen pengadaan sarana } \\
\text { - Manajemen pemeliharaan sarana } \\
\text { dan prasarana } \\
\text { - Manajemen penggunaan sarana } \\
\text { dan prasarana }\end{array}$ \\
\hline & & $\begin{array}{l}\text { Aplikasi GIS } \\
\text { (Geography } \\
\text { Information } \\
\text { Systems) }\end{array}$ & $\begin{array}{l}\text { - Memantau luas wilayah bencana } \\
\text { - Pencegahan terjadinya bencana } \\
\text { pada masa datang } \\
\text { - Menyusun rencana-rencana } \\
\text { pembangunan kembali daerah } \\
\text { bencana }\end{array}$ \\
\hline & & $\begin{array}{c}\text { Aplikasi } \\
\text { Sistem Logistik }\end{array}$ & $\begin{array}{l}\text { - Manajement pendistribusian logistik } \\
\text { - Manajement pemeliharaan logistic } \\
\text { - Manajement pengadaan dan } \\
\text { pengudangan logistik }\end{array}$ \\
\hline & & $\begin{array}{r}\text { Aplikasi } \\
\text { manajement } \\
\text { finansial }\end{array}$ & $\begin{array}{l}\text { - Manajement finansial yang masuk } \\
\text { dan keluar } \\
\text { - Manajemen finansial untuk } \\
\text { penanggulangan bencana }\end{array}$ \\
\hline
\end{tabular}

\section{b. Perbandingan Data}

Bila dibandingkan data yang digunakan saat ini dengan data yang akan digunakan pada sistem yang akan datang, maka terlihat ada perbedaan gap yang besar. Ada beberapa data saat ini yang dapat digunakan pada sistem yang akan dikembangkan. Secara lengkap perbedaan data pada sistem existing dengan sistem yang akan datang dapa dilihat pada Tabel 10 di bawah ini 
Tabel 10 Perbandingan data existing dengan data yang diusulkan

\begin{tabular}{|c|l|}
\hline Data Existing & \multicolumn{1}{|c|}{ Data yang akan datang } \\
\hline Data Bencana & Data Sarana \\
\hline $\begin{array}{c}\text { Data Lokasi } \\
\text { Infrastruktur }\end{array}$ & Data Prasarana \\
\hline $\begin{array}{c}\text { Data kerusakan } \\
\text { Properti }\end{array}$ & Data Pemeliharaan \\
\hline & Data Pengadaan \\
\hline & Data Lokasi \\
\hline & Data Media \\
\hline & Data Sarana PD \\
\hline & Data Pemeliharaan Sarana PD \\
\hline & Data Bencana \\
\hline & Data Korban \\
\hline & Data Lokasi \\
\hline & Data Kerusakan Infrastruktur \\
\hline & Data Kerusakan Properti \\
\hline & Data Pengungsian \\
\hline & Data Bantuan \\
\hline & Data Distribusi Bantuan \\
\hline & Data Lembaga Donor \\
\hline & Data Posko Bencana \\
\hline & Data Relawan \\
\hline & Data Pencarian \\
\hline & Data Tim SAR \\
\hline & Data Assigment Relawan \\
\hline & Data Kerusakan Infrastruktur \\
\hline & Data Kerusakan Properti Korban \\
\hline & Data Korban \\
\hline & Data Perawatan Medis \\
\hline & Data Tenaga Medis \\
\hline & Data Rumah Sakit \\
\hline & Data Relawan \\
\hline & Data Organisasi/LSM \\
\hline & Data Assigment \\
\hline & Data Infrastruktur \\
\hline & Data Properti Masyarakat \\
\hline & Data Proyek \\
\hline & Data Pendanaan \\
\hline & Data Lembaga Pembelian Dana \\
\hline & Data Vendor \\
\hline & \\
\hline & \\
\hline & \\
\hline &
\end{tabular}

\section{Fase Migration Planning}

Pendekatan yang digunakan untuk menentukan urutan pengembangan aplikasi dalam tanggap darurat adalah berdasarkan kebutuhan urgensi masalah, manfaat bagi pelayanan terhadap korban

dampak bencana, peningkatan pelayanan bagi korban bencana dan manajemen pengelolaan tanggap darurat.

Tabel 11 Urutan penerapan modul aplikasi

\begin{tabular}{|c|c|c|}
\hline No & Prioritas Project & Kandidat urutan modul aplikasi \\
\hline \multirow[t]{3}{*}{1.} & \multirow{3}{*}{$\begin{array}{l}\text { Manfaat bagi peningkatan } \\
\text { pelayanan terhadap korban } \\
\text { dampak bencana }\end{array}$} & Aplikasi korban dan kerusakan bencana \\
\hline & & Aplikasi penanganan medis dan SAR \\
\hline & & Aplikasi Sistem Logistik \\
\hline
\end{tabular}




\begin{tabular}{|c|c|c|}
\hline & & Aplikasi simulasi dan assessment bencana \\
\hline \multirow[t]{4}{*}{2.} & \multirow{4}{*}{$\begin{array}{l}\text { Perbaikan proses tanggap } \\
\text { darurat }\end{array}$} & Aplikasi pengelolaan relawan \\
\hline & & Aplikasi Infrastruktur Data Spasial Bencana \\
\hline & & Aplikasi sistem informasi SDM \\
\hline & & Aplikasi manajement finansial \\
\hline \multirow[t]{3}{*}{3.} & \multirow{3}{*}{$\begin{array}{l}\text { Manajement pengelolaan } \\
\text { tanggap darurat }\end{array}$} & Aplikasi pengelolaan saran dan prasarana \\
\hline & & Aplikasi pengelolaan Kerjasama \\
\hline & & $\begin{array}{c}\text { Aplikasi program rehabilitasi } \\
\text { bencana }\end{array}$ \\
\hline
\end{tabular}

Manajemen pengelolaan tanggap darurat bettujuan untuk memperbaiki pelayanan kepada masyarakat setelah teljadi bencana dan melakukan penanganan trauma bencana. Pengelolaan tanggap darurat masih banyak dilakukan dengan cara yang manual, sehingga mengakibatkan banyak kesalahan- kesalahan yang terjadi.

Berdasarkan pertimbangan di atas, maka diperoleh urutan prioritas aplikasi yang akan dikerjakan. Urutan pengembangan aplikasi dapat dilihat pada Tabel 11 di atas.

\section{Kesimpulan}

Berdasarkan penelitian yang sudah dilakukan, maka dapat diambil kesimpulan sebagai berikut:

1. Membangun Sistem informasi tanggap darurat perlu dilakukan dengan proses yang benar dan harus memastikan setiap Sistem informasi yang dikembangkan beljalan sesuai dengan dengan undang-undang yang berlaku

2. Pemilihan teknologi yang tepat dengan mempertimbangkan teknologi yang tersedia saat ini dan arah perkembangan tekno|ogi

3. Memastikan teknologi yang digunakan dapat berfungsi dengan maksimal dan dapat meminimal masalahmasalah yang terjadi yang diakibatkan pasca tanggap darurat.

\section{Referensi}

1. BNPB.UU.No.24. (2007). UNDANG-UNDANG REPUBLIK INDONESIA NOMOR 24 TAHUN 2007 Tentang Penanggulangan bencana.

2. nasional.republika.co.id. (2017, Desember 5). Sepanjang 2017, 1.500 Bencana Ten'adi di Jawa Barat. (R. N. Iman, Ed.) Retrieved 4 12, 2018, from

http://nasional.republika.co.id/berita/nasional/daerah/17/12/05/p0hdnb282-sepanjang-2017 1500bencana-terjadi-di-jawa-barat

3. Hamzah Malikul, Sophan K.M, Kustiyaningsih Yeni, 2012. "Perancangan Sistem Informasi Badan Kepegawaian daerah (BKD) Bangkalan Sebagai Sub Sistem dari E»Govermment Bangkalan Menggunakan TOGAF ADM"

4. Sadisun, Imam, Dr.Eng. Pemahaman Karakter/Lcfik Bencana: Aspek Fundamental dalam Upaya Mitigasi dan Penanganan Tanggap Darurat Bencana. Pusat Mitigasi Bencana-ITB

5. C10 Council (1999). Federal Enterprise Architecture Framework. Version 1.1 http://www.enterprisearchitecture.info/Images/Documents/FederaI\%20EA\%20 Framework.pdf. Diakses 12 April 2014

6. http://pubs.opengroup.org/architecture/togaf8-doc/arch/, diakses 11 April 2014 